\title{
Job Attribute Preference of Executives: A Conjoint Analysis
}

\author{
Shakila Yasmin ${ }^{1}$, Khaled Mahmud ${ }^{1} \&$ Farzana Afrin ${ }^{2}$ \\ ${ }^{1}$ Institute of Business Administration, University of Dhaka, Bangladesh \\ ${ }^{2}$ BBS Cables Ltd., Dhaka, Bangladesh \\ Correspondence: Shakila Yasmin, Institute of Business Administration, University of Dhaka, Dhaka, Bangladesh. \\ Tel: 880-018-1752-5231. E-mail: shakila@iba-du.edu
}

Received: November 19, 2015 Accepted: December 11, 2015 Online Published: January 12, 2016

doi:10.5539/ass.v12n2p68 URL: http://dx.doi.org/10.5539/ass.v12n2p68

\begin{abstract}
This research explores the job attribute preferences of executives in Bangladesh. Unlike most past researches that deployed isolated estimation methods, this research used conjoint analysis, a marketing research tool to measures the relative utilities and trade-off matrices of different job attributes. Data was collected from 140 executive MBA students from a premier business school in Dhaka using a questionnaire presenting an array of hypothetical job offers. Salary \& benefit and person-job match are found to be the top two most preferred job attributes. Workenvironment and company- reputation are indicated as the two least important job attributes. Simulation was run to demonstrate the trade-offs people make in their job choice decisions. Case-wise conjoint results show no significant difference among different demographic groups (e.g. married-single, have-don't have dependents and others) in terms of the order of importance of the job attributes. However, the value of the relative importance was found to be slightly different for different demographic groups.This research is important for academics as it demonstrate a new technique to analyze job attribute preferences. Managers can use the results of this study for designing jobs to attract and retain the best talents of the market. They can use the simulation process demonstrated here for optimizing overall preference of their job offers.
\end{abstract}

Keywords: Job attributes, conjoint analysis, Bangladesh, preference of executives

\section{Introduction}

This research explores the job attribute preferences of executives. It also focuses on the relative utilities and possible trade-offs executives are ready to make among different job attributes. Job attributes are different aspects of a job that fulfill material, social and higher order needs such as growth, self-expression, esteem and others of employees (Pinder, 1998). In other words, job attributes are the components, qualities, and payoffs of a job that determines the attractiveness of that particular job to a person (Konrad, Ritchie, Lieb, \& Corrigall, 2000a). Knowledge about the importance employees/ potential employees place on various job attributes and possible trade-offs thereby is important for recruiting managers. This knowledge is likely to provide insights for job design; compensation planning and other areas of human resources management as such to help managers have their top choices to accept their joboffer and retain high-performing employees in the organization.

There are many studies focusing on job attribute. For example, Jurgensen (1978) got 10 job attributes ranked by the subjects by asking what was most important to them in a job. Based on data collected from all job applicants of a utility company over the period 1945-1975 he found that security was most important job attribute for men whereas the type of work was most important for women. Interviews of 6,902 workers in OECD countries depict that job security and interest are the most important aspect of job followed by promotion opportunity and ability to work independently (Clark, 1998). Pay and hours of work have been found to be the least rated attributes (Davis \& Jowell, 1989). Sutherland (2011) used 2006 Skills Survey data, UK and found that job security, interest, friendly environment and opportunity to use one's abilities are the most preferred job attributes.

Many studies such as Corrigall \& Konrad (2006); Konrad (2003); Konrad, Corrigall, Lieb, \& Ritchie (2000b); Tolbert \& Moen (1998); Browne (1997) and others have focused on gender differences of job attribute preference. Besides gender, influence of variables like culture, family responsibility, age etc. on job attribute preference has been demonstrated in the literature (Konrad, 2003; Tolbert \& Moen, 1998; Browne, 1997 and others). Through longitudinal analysis researchers such as Sutherland (2011), Konrad (2003), Tolbert \& Moen (1998) and others indicate that preferences are not static, they change over time. 
But almost all studies on this topic have deployed isolated estimation methods where respondents were asked to indicate the importance of particular job attributes on scales ranging not important at all to very important (Turban \& Campion, 1993). Such isolated estimation is problematic because they are not linked to overall employment decision (Schwab, Rynes, \& Aldag, 1987). Isolated ratings (degree of importance) ignore possibilities of trade-off when bundled in a job offer. People do trade-offs while making decision to accept/reject job offers (Andersen et al., 2012). To address this problem with isolated rating, this research, unlike most previous studies, presents hypothetical job offers (consisting of particular values of the job attributes) to the subjects and asks them how likely they are to accept that hypothetical job. Numbers of job offers were serially (one after another) presented before the subjects.

\subsection{Objective}

This study intends to investigate job attribute preferences of executives in Bangladesh. Here executive means people employed in management ranks and having more than three years of working experience. To meet the above broad objective following specific objectives are pursued.

- Identify major job attributes that influence job choice decision.

- Identify the common values each job attribute can take. These common values or ranges of values are referred as levels in this paper.

- Measure average utilities of each levelunder each job attribute.

- Measure relative importance of each of the job attributes.

- Demonstrate the trade-offs people make in job choice decision by running the simulation.

- Investigate whether there are any differences in job attribute preferences among different demographic groups such as male-female, married-single, have dependence- do not have dependence and others.

\subsection{Research Method}

The paper conceives jobs (job offers) as a product to be sold among prospective employees by the employer/ recruiting manager. Here job attributes are product features/attributes that employees get as they accept (purchase) a job offer. Price paid/charged for the product (job) is the commitment of their labor, talent and services to the organization. Such conceptualization in marketing terms, lead the researchers to use market research tool, conjoint analysis usually used for product design, for job design (Wilcox, 2008; Kreiger \& Wind, 2001). Conjoint analysis allows to consider features (job attributes) jointly.

\subsubsection{Conjoint Analysis}

Conjoint analysis is a measurement technique originated in the field of mathematical psychology and psychometrics (Green \& Srinivasan, 1978). In recent days, it has been used as a marketing research tool to measure the relative importance of a product attributes. Starting with an overall judgment about a set of composite alternatives consisting different values of the attributes; it determines how consumers value different attributes of the product as a whole. By decomposing original responses into separate utility scale for each attribute the trade-offs consumers are willing to make among different attributes can be measured (Green, Krieger, \& Wind, 2001). Such knowledge is important for product design, modifying existing products and planning marketing strategies.

After gathering an exhaustive list of attributes from different literatures and expert opinions, researchers tested those on a survey of 30 executive MBA students to refine the list. Two focus groups with executives were conducted to further refine the attributes and to develop levels for each attribute. Researchers kept eight major attributes based on thefeedbackof focused group study.

In conjoint analysis, as the number of attributes and levels (ranges of values) of the attribute increases the number of hypothetical offers of the product increases and thus boosts requirement of data (Wilcox, 2008). Moreover, asking for responses about numerous product- offers is likely to reduce the quality of data due to respondents' fatigue. Therefore, unlike most previous researches that used 10-15 job attributes and many of them have categorized attributes as extrinsic and intrinsic, this study used only eight job attributes namely salary \& benefits, job security, work hour, opportunity for growth, work environment, person-job match, corporate reputation and opportunity to make important decisions (related to the job and the company).

\subsection{Job Attributes}

The definitions and levels of the attributes used in this research are presented below- 


\subsubsection{Salary \& Benefits}

Salary is considered as the gross monetary payment from a job. Benefits include non-monetary facilities such as company housing, transport facility, medical insurance and others provided by the employer. The main purpose of working is to earn for livelihood and lifestyle. So this is one of the topmost job attribute that people care about. In Jurgensen's (1978) study of 10 job attributes benefits was found to be the second most preferred, whereas pay was found to be the sixth preferred attribute. Despite nonadjacent position of salary and benefits on the preference scales of most past researches, this research bundles them together on the ground that both are the pay-offs from a job for maintaining lifestyle. Therefore for the purpose of this study benefits are estimated in monetary terms and then added to salary, thereby considered as one job attribute. Based on average salary\& benefits statistics of executives in Bangladesh three levels of salary i.e. below Taka80000, Tk80000- Taka120000, above Taka120000 per month have been taken into account.

\subsubsection{Job Security}

Job security is the aspect that measures the implausibility of job loss. High job security means, it is very unlikely that there will be job loss. In contrast, low job security means high chances of job loss. Although, over-arching (economy wide) job loss is driven by overall economic condition of country/ region; jobs in some industries and or organizations are less secured compared to others. Competition, product/industry life cycle, financial health of the company, organizational culture and others influence job security. Researches in the past have found job security to be an important job attribute (Sutherland, 2011; Clark, 1998; Jurgensen, 1978 and others). This study takes two levels (i.e. high and low) of job security.

\subsubsection{Work Hour}

Work hour means number of hours worked per week. It can also mean flexibility in work hour. Work hour is considered flexible when an employee gets the opportunity to choose his/her work schedule. But this study represents work hour as the required number of hours to work in a week. Long work hour has been identified as a negative attribute of today's jobs (Sutherland, 2011; Corrigall \& Konrad, 2006; Reynolds, 2005; Konrad, 2003). Even earlier studies such as Clark (1998) and Jurgensen (1978) has identified work hour as an important attribute that influence individual's job choice decision.

Full time employees are officially required to work 40 hours per week (ILO, 1962). But today's jobs, particularly in the private sector, are much more demanding. Most executives today spend 45 to 70 hours per week (Reynolds, 2005). Based on the above statistics three levels of work hour namely below $45 \mathrm{hrs} . / \mathrm{w}, 45-55 \mathrm{hrs} . / \mathrm{w}$ and above $55 \mathrm{hrs}$. $/ \mathrm{w}$ has been taken for this study.

\subsubsection{Opportunity for Growth}

Opportunity for growth means having scope for learning and moving up the organizational ladder (promotion). Learning makes one more capable and eligible for promotion. Increase in salary \& benefit, authority \& power for decision making andprestige comes with promotion. Hence, it is a generally preferred job attribute. Empirical studies such as Sutherland (2011), Corrigall \& Konrad (2006), Konrad (2003), and Jurgensen (1978) andothers ranked advancement or opportunity for growth at the top of preference among different job attributes. People usually do not want to get into jobs with no or limited growth opportunity. This study considers two levels of opportunity for growth; high and low.

\subsubsection{Work Environment}

Work environment may mean relational and physical aspects of the workplace (Konrad et al., 2000a; Tolbert \& Moen, 1998 and others). Relational aspects include culture of the organization regarding relationship with peers, managers, and subordinates and physical aspects include health and safety condition of the workplace. This study covers only the relational aspect. As the study is about job choice (accepting a job offer) relational aspect only can cover a general overview of the relationships in the organization. Actual relationship with colleagues is unknown at the point of decision. Therefore, levels are chosen to be semi-formal/ casual and strictly formal. Business-casual out-fit, friendly discussions and talking on topics beyond work are some characteristics of semi-formal/ casual environment. In strictly formal environment people dress formal, talk in a low tone, don't discuss about family and personal matters.

\subsubsection{Company Reputation}

Reputation of an organization is a multidimensional construct. Factors ranging from economic performance, caring for employees and external stakeholders, ethics in doing business, to media visibility affect fortune 500 reputation of companies (Fombrun \& Shanley, 1990). Reputation of a company varies based upon the domain of 
interest and audience.However, in general terms, a widely known company that is well accepted in delivering customer value, not doing any harm to society and doing business ethically is considered to be reputed. Rynes (1989) suggested that general impression of organizational attractiveness that she phrases as corporate image (or reputation in this research) is an important factor of job choice decision. Gatewood, Gowan, \& Lautenschlager (1993); Fombrun \& Shanley (1990); Belt \& Paolillo (1982) and others indicated that corporate reputation is a major component of job choice decisions. This research is not about rating corporate image or reputation rather it intends to identify job attributes that affect job choice. No matter how reputation is conceived by the respondents, the importance they place on reputation in their job-choice decision is important for this research. Therefore, the researchers did not demonstrate any definition of reputation to the respondents rather relied on respondents' own conception of that. Two levels of reputation; reputed/somewhat reputed and not reputed was used to create the hypothetical job offers for this research.

\subsubsection{Person-Job Match}

Here the person refers to his/her interest \& qualifications and the job refers to job characteristics and requirements. Empirical studies have found that current interests of individuals strongly influence their choice of career in relevant areas. For example, Jacobs et al. (1998) reported that current interest in science was strongly related to young women's preferences for science careers. Morgan, Isaac \& Sansone (2001) demonstrated that most college students they surveyed desire interesting work in their job choice decision. Other studies reveal that having relevant background (education, training \& experiences) makes a person confident to take a job and perform well (Lauver \& Kristof-Brown, 2001; Turban et al., 1993; Miller, 1984). Therefore, person-job match is an important component of job choice decision. Three levels of person-job match weretaken e.g. perfect match, somewhat match and not match.

\subsubsection{Involvement in Decision Making}

Opportunity for making important decisions related to the job and the company meets the esteem need of people (Maslow, 1943). Jobs that allow employees to participate in decision making in the form of setting goals, organizational policies \& strategies, controlling subordinates and others are considered as important/significant jobs (Herzberg, 1966). In other words, authority to take decision is perceived as power and status. People often are ready to sacrifice pay for authority to make a decision (Fehr, Herz, \& Wilkening, 2013). For the purpose of this research two levels of involvement in decision making is taken e.g., high and low.

\subsection{Demographic Variables}

Many of the early researches, focused on investigating the effect of gender and/or family responsibilities on the relative importance of the job attributes (Sutherland, 2011; Corrigall \& Konard, 2006; Konrad, 2003; Konrad et al., 2000 and others). By family responsibility most researches meant taking part in household care work. But this research, rather than focusing directly on gender and participation in household work focused on having dependents, marital status, and age. Given the socio-economic structure of Bangladesh few men take part in household work, so the researchers thought having dependents or being married are the proxy of family responsibility in financial terms (paying for food, dwelling, and other expenses) and thereby took marital status and having dependents as two relevant demographic variable for the study. Another demographic variable taken for analysis was experience or career stage. Respondents were classified in three groups with respect to their years of experience e.g. less than 6 years' experience, between 6 to 10 years' experience and more than 10 years of experience.

\subsection{The Survey Instrument}

Using the eight job attributes and their levels presented above an orthogonal design was created in SPSS16.0. The orthogonal design is a computer generated an array of product (job) attribute combinations. Each combination is considered as a choice card (in this case hypothetical job offer) for respondents. Using random seed 10, 16 hypothetical job offers (HJO) were created. A questionnaire with the HPOs and some other demographic questions was created for the survey. Respondents were asked how likely they were to choose a particular HJO.

\subsection{The Survey}

The questionnaire was provided to 140 executive MBA students in a business school in Dhaka, Bangladesh. This group of students is a representative sample of the executives of the country, because: a) at least three years of working experience as an executive is a prerequisite for admission in the Executive MBA program and b) students come from many different industry sectors. A short briefing about how to complete the survey was provided before respondents started filling the questionnaires. Data were collected in presence of the researchers 
to ensure complete responses on all HJOs. However, 20 responses were found not to be useful because these respondents did not respond to all the HJOs presented in the questionnaires.

Table 1. Demographics of respondents

\begin{tabular}{cccc}
\hline Variable & Description & Count $(n=140)$ & Percent (\%) \\
\hline \multirow{2}{*}{ Gender } & Male & 129 & 92.1 \\
& Female & 11 & 7.9 \\
\multirow{3}{*}{ Year of Experience } & $3-5$ years & 69 & 49.3 \\
& $6-$ 10 years & 48 & 34.3 \\
& More than 10 years & 23 & 16.4 \\
Marital Status & Single & 51 & 36.4 \\
& Married & 89 & 63.6 \\
Number of Dependent & None & 24 & 17.1 \\
& 1 to 3 & 91 & 65.0 \\
& More than 3 & 25 & 17.9 \\
& Entry Level & 23 & 16.4 \\
Current Job Level & Mid-Level & 106 & 75.7 \\
& Senior Level & 11 & 7.9 \\
\hline
\end{tabular}

\section{Results}

\subsection{Estimated Utilities}

The Conjoint analysis run on SPSS 16.0 statistically deducedrelative values the respondents have subconsciously assigned on each level of the job attributes presented before them. Averaged part-worths of the SPSS output are arbitrary interval measures of the utilities associated with each level of a job attribute. These utility estimates of each level of all the attributes covered in this research are presented in the following table. Here negative utility means less preference on average. Salary \& Benefit more than BDT120000 has the highest part-worth or estimated utility, and that less than BDT80000 has the lowest utility. Perfect person-job match depicts second highest utilitywhereas no person-job match shows second least utility. This means, salary \& benefit and person-job match are the top two most preferred job attributes.

Table 2. Levels of Job attributes and average part-worths (utility estimates)

\begin{tabular}{|c|l|c|}
\hline Attribute & \multicolumn{1}{|c|}{ Level } & Part-warths \\
\hline \multirow{3}{*}{ Salary \& Benefit } & More than BDT 120000 & 0.658 \\
\cline { 2 - 3 } & EDT 80000 to BDT 120000 & 0.031 \\
\cline { 2 - 3 } & Less than BDT 80000 & -0.689 \\
\hline \multirow{3}{*}{ Work Hour } & Less than 45 hours & 0.145 \\
\cline { 2 - 3 } & 45 to 55 Hours & -0.004 \\
\cline { 2 - 3 } & More than 55 hours & -0.14 \\
\hline \multirow{2}{*}{ Growth Op portunity } & High & 0.244 \\
\cline { 2 - 3 } & Low & -0.244 \\
\hline \multirow{2}{*}{ Work Environment } & Semi-formal to Casual & 0.096 \\
\cline { 2 - 3 } & Strictly Formal & -0.096 \\
\hline \multirow{2}{*}{ Person-Job Match } & Ferfect Match & 0.58 \\
\cline { 2 - 3 } & Somewhat Match & 0.071 \\
\cline { 2 - 3 } & Ho Match & -0.651 \\
\hline \multirow{2}{*}{ Job Security } & High & 0.49 \\
\cline { 2 - 3 } & Low & -0.49 \\
\hline \multirow{2}{*}{ Com pany Reputation } & High to Middle & 0.199 \\
\cline { 2 - 3 } & Middle to Low & -0.199 \\
\hline \multirow{2}{*}{ Involvem ent in Decision Making } & High & -0.449 \\
\cline { 2 - 3 } & Low & \\
\hline
\end{tabular}


The conjoint results have high level of significance as represented by Pearson's coefficient of 0.995 and p-value 0.000 . This indicates that high level of correlation exists between the observed and estimated preferences (Wilcox, 2008).

\subsection{Relative Importance}

Variance of the estimated utilities within the levels of a given attribute in relation to that of other attributes measures the relative importance of a particular attribute. Following bar chart presents the relative importance of the job attributes.

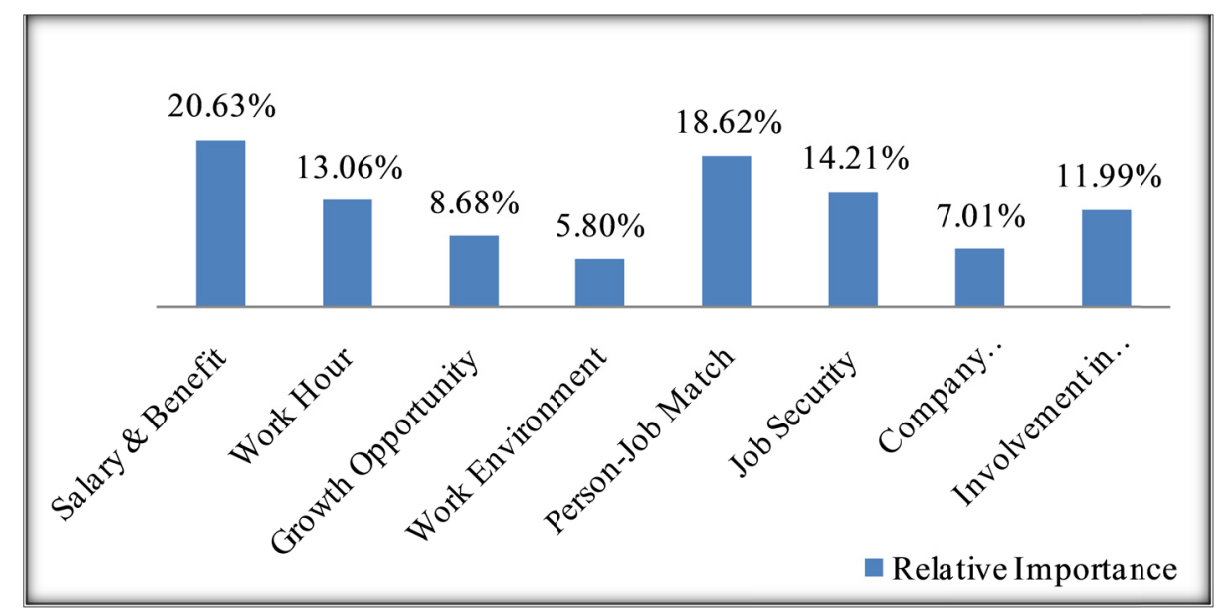

Figure 1. Relative importance of the job attributes

Results show that salary\& benefitsare the most important attribute of job choice decision with a relative importance of $20.634 \%$ attached to it. Person-job match isthe second most important factor (relative importance $18.62 \%$ ) followed by job security (relative importance $14.207 \%$ ). In a lower-middle income country like ours, it is very usual to value the income factor highly. Work hour is ranked $4^{\text {th }}$ in terms of importance. It seems that executives are not very worried about the extended work hours. Unlike most other studies such as Corrigall \& Konrad (2006), Turban et al. (1993) and others, relative importance for growth opportunities is found to be very low, only $8.676 \%$ (ranked $6^{\text {th }}$ out of 8 attributes). Work environment and company reputation although has been identified as important factors of job choice decision in previous studies (Gatewood et al., 1993; Fombrun \& Shanley, 1990; Belt \& Paolillo, 1982 and others) according to this study, they are the two least important attributes.

\subsection{Simulation}

Simulation was run to demonstrate the trade-offs people make in their job choice decision. How changing different attributes affect overall preference of the HJOs is revealed (Wilcox, 2008; McCullough, 2002). For running simulation, a base case job offer was created by keeping the 3 least important attributes at their highest utility level and the rest attributes at medium/lower utility levels. Keeping everything else as is and by changing involvement in decision-making to a high level a new offer was created. To see how this new offer performs against the base offer, simulation was run. The output shows that new offer is preferred than the base offer with a share of preference $56.4 \%$ (as indicated by Bradley-Terry-Luce in simulation table). This means that if an organization that has the attributes of the base case increases involvement in decision making $56.4 \%$ of the respondents are likely to prefer that over the base case (McCullough, 2002). Following the same procedure, other attributes of the base case are changed one at a time to the higher utility level and simulation is run to see changes in which of the attributes has a greater impact on preference. Results are shown in the Table3: Simulation 1.

Results show that increase in job security has the highest preference share. This means, increased job security has the most impact on changing preference from the base case. This job offer was then taken as the base case for second stage simulation. By changing the other attributes one at a time to their highest utility level simulation is run again. Results are presented in the Table: Simulation 2. In the same manner simulations of stages 3 and 4 are run. Results are presented in tables Simulation 3 and Simulation 4 respectively. 
Table 3. Simulation 1

\begin{tabular}{|c|c|c|c|c|c|c|}
\hline Job Attribute & Base case & Round 1 & Round 2 & Round 3 & Round 4 & Round 5 \\
\hline Salary \& Benefit & $\begin{array}{l}\text { BDT80,000 to } \\
\text { BDT 120,000 }\end{array}$ & $\begin{array}{l}\text { BDT } 80,000 \text { to } \\
\text { BDT } 120,000\end{array}$ & $\begin{array}{l}\text { BDT } 80,000 \text { to } \\
\text { BDT } 120,000\end{array}$ & $\begin{array}{l}\text { BDT } 80,000 \text { to } \\
\text { BDT } 120,000\end{array}$ & $\begin{array}{l}\text { BDT80,000 to } \\
\text { BDT120,000 }\end{array}$ & $\begin{array}{l}\text { More than } \\
\text { BDT120,000 }\end{array}$ \\
\hline $\begin{array}{l}\text { Pers on-Job } \\
\text { Match }\end{array}$ & $\begin{array}{l}\text { Some-what } \\
\text { match }\end{array}$ & $\begin{array}{l}\text { Some-what } \\
\text { match }\end{array}$ & $\begin{array}{l}\text { Some-what } \\
\text { match }\end{array}$ & $\begin{array}{l}\text { Some-what } \\
\text { match }\end{array}$ & Perfec-t match & $\begin{array}{l}\text { Some-what } \\
\text { match }\end{array}$ \\
\hline Job Security & Low & Low & Low & High & Low & Low \\
\hline Work Hour & 45 to $55 \mathrm{hrs}$ & 45 to $55 \mathrm{hrs}$ & $<45 \mathrm{hrs}$ & 45 to $55 \mathrm{hrs}$ & 45 to $55 \mathrm{hrs}$ & 45 to $55 \mathrm{hrs}$ \\
\hline $\begin{array}{l}\text { Involvement in } \\
\text { Decision making }\end{array}$ & Low & High & Low & Low & low & 10w \\
\hline $\begin{array}{l}\text { Growth } \\
\text { Opportunity }\end{array}$ & High & High & $\mathrm{High}$ & High & High & High \\
\hline $\begin{array}{l}\text { Company } \\
\text { Reputation }\end{array}$ & High & High & High & High & High & High \\
\hline $\begin{array}{l}\text { Work } \\
\text { environment }\end{array}$ & $\begin{array}{l}\text { Semi-formal/ } \\
\text { Casual } \\
\end{array}$ & \begin{tabular}{|l|} 
Semi-formal/ \\
Casual \\
\end{tabular} & $\begin{array}{l}\text { Semi-formal/ } \\
\text { Casual }\end{array}$ & $\begin{array}{l}\text { Semi-formal/ } \\
\text { Casual }\end{array}$ & $\begin{array}{l}\text { Semi-form al/ } \\
\text { Casual }\end{array}$ & $\begin{array}{l}\text { Semi-formal/ } \\
\text { Casual }\end{array}$ \\
\hline $\begin{array}{l}\text { Bradley-terry- } \\
\text { luce }\end{array}$ & - & 0.564 & 0.513 & 0.567 & 0.541 & 0.548 \\
\hline
\end{tabular}

Table 4. Simulation 2

\begin{tabular}{|c|c|c|c|c|c|}
\hline Job Attribute & Base case & Round 1 & Round 2 & Round 3 & Round 4 \\
\hline Salary \& Benefit & $\begin{array}{l}\text { BDT } 80,000 \text { to } \\
\text { BDT } 120,000\end{array}$ & $\begin{array}{l}\text { BDT80,000 to } \\
\text { BDT120,000 }\end{array}$ & $\begin{array}{l}\text { BDT } 80,000 \text { to } \\
\text { BDT } 120,000\end{array}$ & $\begin{array}{l}\text { BDT } 80,000 \text { to } \\
\text { BDT } 120,000\end{array}$ & $\begin{array}{l}\text { More than } \\
\text { BDT120,000 }\end{array}$ \\
\hline $\begin{array}{l}\text { Person-Job } \\
\text { Match }\end{array}$ & $\begin{array}{l}\text { Some -what } \\
\text { match }\end{array}$ & $\begin{array}{l}\text { Some -what } \\
\text { match }\end{array}$ & $\begin{array}{l}\text { Some-what } \\
\text { match }\end{array}$ & Perfect match & $\begin{array}{l}\text { Some -what } \\
\text { match }\end{array}$ \\
\hline Job Security & High & High & High & High & High \\
\hline Work Hour & 45 to $55 \mathrm{hrs}$ & 45 to $55 \mathrm{hrs}$ & Less than $45 \mathrm{hrs}$ & 45 to $55 \mathrm{hrs}$ & 45 to $55 \mathrm{hrs}$ \\
\hline $\begin{array}{l}\text { Involvement in } \\
\text { Decision making }\end{array}$ & Low & High & Low & Low & $10 \mathrm{w}$ \\
\hline $\begin{array}{l}\text { Growth } \\
\text { Opportunity }\end{array}$ & High & High & High & High & High \\
\hline $\begin{array}{l}\text { Company } \\
\text { Reputation }\end{array}$ & High & High & High & High & High \\
\hline $\begin{array}{l}\text { Work } \\
\text { environment }\end{array}$ & $\begin{array}{l}\text { Semi-formal/ } \\
\text { Casual }\end{array}$ & $\begin{array}{l}\text { Semi-formal/ } \\
\text { Casual }\end{array}$ & $\begin{array}{l}\text { Semi-formal/ } \\
\text { Casual }\end{array}$ & $\begin{array}{l}\text { Semi-formal/ } \\
\text { Casual }\end{array}$ & $\begin{array}{l}\text { Semi-formal/ } \\
\text { Casual }\end{array}$ \\
\hline $\begin{array}{l}\text { Bradley-terry- } \\
\text { luce }\end{array}$ & - & $57.20 \%$ & $57.10 \%$ & $54.90 \%$ & $55.30 \%$ \\
\hline
\end{tabular}

Table 5. Simulation 3

\begin{tabular}{|l|l|l|l|l|}
\hline Job Attribute & Base case & Round 1 & Round 2 & Round 3 \\
\hline Salary \& Benefit & $\begin{array}{l}\text { BDT 80000 to } \\
\text { BDT 120000 }\end{array}$ & $\begin{array}{l}\text { BDT 80000 to } \\
\text { BDT 120000 }\end{array}$ & $\begin{array}{l}\text { BDT 80000 to } \\
\text { BDT 120000 }\end{array}$ & $\begin{array}{l}\text { More than } \\
\text { BDT 120000 }\end{array}$ \\
\hline $\begin{array}{l}\text { Person-Job } \\
\text { Match }\end{array}$ & $\begin{array}{l}\text { Some -what } \\
\text { match }\end{array}$ & $\begin{array}{l}\text { Some -what } \\
\text { match }\end{array}$ & Perfect match & $\begin{array}{l}\text { Some -what } \\
\text { match }\end{array}$ \\
\hline Job Security & High & High & High & High \\
\hline Work Hour & 45 to 55 hrs & $<45$ hrs & 45 to 55 hrs & 45 to 55 hrs \\
\hline $\begin{array}{l}\text { Involvement in } \\
\text { Decision making }\end{array}$ & High & High & High & High \\
\hline $\begin{array}{l}\text { Growth } \\
\text { Opportunity }\end{array}$ & High & High & High & High \\
\hline $\begin{array}{l}\text { Company } \\
\text { Reputation }\end{array}$ & High & High & High & High \\
\hline $\begin{array}{l}\text { Work } \\
\text { environment }\end{array}$ & $\begin{array}{l}\text { Semi-formal/ } \\
\text { Casual }\end{array}$ & $\begin{array}{l}\text { Semi-formal/ } \\
\text { Casual }\end{array}$ & $\begin{array}{l}\text { Semi-formal/ } \\
\text { Casual }\end{array}$ & $\begin{array}{l}\text { Semi-formal/ } \\
\text { Casual }\end{array}$ \\
\hline $\begin{array}{l}\text { Bradley-terry- } \\
\text { luce }\end{array}$ & - & $55.30 \%$ & $53.30 \%$ & $50 \%$ \\
\hline
\end{tabular}


Table 6. Simulation 4

\begin{tabular}{|l|l|l|l|}
\hline Job Attribute & Base case & Round 1 & Round 2 \\
\hline Salary \& Benefit & $\begin{array}{l}\text { BDT } 80000 \text { to } \\
\text { BDT 12000 }\end{array}$ & $\begin{array}{l}\text { BDT 80000 to } \\
\text { BDT 120000 }\end{array}$ & $\begin{array}{l}\text { More than } \\
\text { BDT 120000 }\end{array}$ \\
\hline $\begin{array}{l}\text { Person-Job } \\
\text { Match }\end{array}$ & $\begin{array}{l}\text { Some -what } \\
\text { match }\end{array}$ & Perfect match & $\begin{array}{l}\text { Some -what } \\
\text { m atch }\end{array}$ \\
\hline Job Security & High & High & High \\
\hline Work Hour & $<45$ hrs & $<45$ hrs & $<45$ hrs \\
\hline $\begin{array}{l}\text { Involvement in } \\
\text { Decision making }\end{array}$ & High & High & High \\
\hline $\begin{array}{l}\text { Growth } \\
\text { Opportunity }\end{array}$ & High & High & High \\
\hline $\begin{array}{l}\text { Company } \\
\text { Reputation }\end{array}$ & High & High & High \\
\hline $\begin{array}{l}\text { Work } \\
\text { environment }\end{array}$ & $\begin{array}{l}\text { Semi -form al/ } \\
\text { Casual }\end{array}$ & $\begin{array}{l}\text { Semi-formal/ } \\
\text { Casual }\end{array}$ & $\begin{array}{l}\text { Semi-formal } \\
\text { Casual }\end{array}$ \\
\hline $\begin{array}{l}\text { Bradley-terry- } \\
\text { luce }\end{array}$ & - & $52.70 \%$ & $50 \%$ \\
\hline
\end{tabular}

From the simulation results, it is evident that for this particular base case situation job offer that perfectly matches the interest and qualifications of the candidates, provides compensation of value between BDT 80000 and 120000; has high job security and high level of opportunity for training development $\&$ growth, requires less than 45 work hours per week in a semi-formal/casual work environment in a company with very good image in the industry is likely to be the most preferred job among the respondents.

\subsection{Preferences among Demographic Groups}

Table 7. Relative importance of job attributes among different demographic groups

\begin{tabular}{|l|r|r|r|r|r|r|r|}
\hline Dem ographic variabl es & \multicolumn{2}{|c|}{ Marital status } & \multicolumn{2}{|c|}{ Having dependents } & \multicolumn{3}{|c|}{ Years of job experience } \\
\hline Job Attribute & \multicolumn{1}{c|}{ Singe } & Marri ed & No dependent & Have dependents & $<6$ years & 6 to 10 years & $>10$ years \\
\hline Salary \& Benefit & 19.876 & 21.069 & 17.709 & 20.554 & 18.225 & 21.958 & 20.634 \\
\hline Work Hour & 12.714 & 13.255 & 14.254 & 13.256 & 12.496 & 13.913 & 13.058 \\
\hline Growth Opportunity & 9.331 & 8.3 & 9.907 & 8.485 & 8.539 & 9.028 & 8.676 \\
\hline Work Environment & 5.996 & 5.694 & 6.789 & 5.713 & 5.748 & 5.464 & 5.804 \\
\hline Person-Job Match & 19.034 & 18.386 & 17.639 & 18.837 & 19.738 & 19.756 & 18.622 \\
\hline Job security & 14.156 & 14.236 & 12.814 & 14.226 & 15.119 & 12.365 & 14.207 \\
\hline Company Reputation & 6.369 & 7.376 & 7.83 & 7.215 & 7.4 & 6.307 & 7.009 \\
\hline Involvement in Dcsion mkg & 12.524 & 11.685 & 13.057 & 11.714 & 12.735 & 11.208 & 11.99 \\
\hline
\end{tabular}

Whether different demographic groups have different preference of job attributes has also been examined. Case-wise conjoint was run. Results show no significant difference among different demographic groups in terms of the order of importance of the job attributes. For example, salary \& benefit is the most important attribute followed by person-job match, job security, and work-hour, involvement in decision making, growth opportunity, company reputation and work environment respectively. However, the value of the relative importance was found to be slightly different for different demographic groups. As presented in the table below, married people have higher importance on salary \& benefit and work hour than single people. Similarly, people who have dependents value salary \& benefit and job security more than those who have no dependents. In fact, married people with dependents have more financial liability, so they are likely to value salary \& benefit and job security higher than others. People with children are likely to value work hour very highly compared to those with no children. Results with respect to years of experience or career stage depict a pattern of life cycle. At the initial stage of career (less than 6 years' work experience) when people are usually single and don't have much family responsibility they value involvement in decision making than the other two groups. People in their mid-career with 6 to 10 years of work experience put more importance on salary \& benefit and growth opportunity than the others because during this stage of career they are likely to have family responsibilities and they expect those 
responsibilities to grow with birth of children and children's education (Sutherland, 2011; Konrad, 2003; Tolbert \& Moen, 1998 and others). Seniors with experience more than 10 years rate job security higher than those at their mid-career but lower than those at early career because given financial liabilities at this stage of life they cannot afford losing jobs.

Gender differences in job attribute preferences revealed in many previous studies could not be tested here because female representation in the sample was too low (only 6 out of 140 responses) to get any statistically significant results.

\section{Discussion and Conclusion}

Most past studies on job attribute preferences asked respondents to rank listed job attributes in order of importance they pay on them while making decision to accept or reject a job offer (Turban et. al., 1993 and Jurgensen, 1978). But ranking after a decision is made might not represent the actual importance on the decision process. Some other studies measured overall job satisfaction level and satisfaction level with a number of extrinsic and intrinsic factors associated with jobs. Then probitregression is run to determine the relative importance of the factors. These researches too were problematic because satisfaction is a state of feelings after experiencing something whereas preference is a 'like to have'condition based on expected outcome. People usually become satisfied by experiencing something as or above expectation. People prefer things and/or factors that they expect to provide full-filling experience above others. This research has tackled the above stated problems of past researches by presenting hypothetical job offers (HJO) to the respondents and asking them how likely they are to accept that HJO. Presentation of HJOs helped in replicating the job choice decision process; hence the responses are likely to be more authentic than those of previous researches.

In the context of Bangladesh, research on job attribute preference is almost non-existent. However, researchers have studied factors affecting job satisfaction, and ranked the importance of those factors on job satisfaction of different employee groups (Kabir \& Parvin, 2011; Islam \& Saha, 2001; Khaleque \& Rahman, 1987 and others). Results of these researches should not be treated as job attribute preference due to the underlying difference between satisfaction and preference. So this research can be considered as unique in terms of not only the methodology applied but also the context.

However, researchers needed to make a trade-off between data quality and comprehensiveness. For a comprehensive analysis, all possible levels of each job attribute should have been taken in designing the HJOs. But this would have increased the number of HJOs to a level that might affect data quality due to respondent fatigue (Wilcox, 2008). Researcher in future can incorporate more levels if they take a smaller number of job attributes for example only the top four or five attributes identified by this and/or other studies.

Early studies in the 70s found job security to be the most and type of work to be the second important attribute (Jurgensen, 1978). Later studies in the 80s and 90s found that type of work is the most important job attribute irrespective of gender and other demographic variables (Konrad, 2003; Clark, 1998; Turban et al., 1993 and others). Type of work is a multifaceted attribute it may mean meaningful work, work that is interesting, challenging, work that offer an opportunity to learn and to use abilities and many others. Different individuals may understand different things by type of work. So, this attribute of previous studies was replaced by person-job match for this study (definition provided earlier in the paper).

Unlike past studies, results of this study show that salary \& benefit is the most important job attribute for all demographic groups in Bangladesh. Top preference of salary\& benefit which has been found to have a low or average importance in other studies may be attributed to the methodological difference of this study. When satisfaction is taken as a proxy of preference, salary \& benefit is likely to have low preference because according to two factor model of motivation this is not a motivator (Herzberg, 1966). Moreover, people have an inherentattitude to showcase altruism (Rose-Ackerman, 1996). They under-represent the importance of monetary benefits when are directly asked to rank among monetary and nonmonetary attributes of a job. This study did not ask the respondents to rank the attributes. The relative importance found from this study actually measured how much importance the respondents sub-consciously placed on the job attributes in their decision to accept/reject the HJOs (Wilcox, 2008). However, the high importance of salary \& benefit can also be attributed to the economic condition (per capita income and living standard) of the country. Person-job match was found to be the second most important attribute, followed by job security, work hour, involvement in decision making and opportunity for growth respectively. In congruence with the socio-economic condition of the country and industries dominated by family owned and run businesses, involvement in decision making and growth opportunity demonstrate low relative importance compared to those in other studies (Rashid \& Lodh, 2008).

This research considered a number of demographic variables such as marital status, having dependence and 
experience/age which were not included in previous studies. However, results show that there is no significant difference among the demographic groups in terms of relative importance of the job attributes. Future researches can conduct an in-depth investigation of the differences among various demographic groups using larger samples taken scientifically from the population.

This research is important for academics as it demonstrate a new technique to analyze job attribute preferences. Researchers in future can take this work to next level by focusing on in-depth analysis of the trade-offs people make in their job attribute preferences. Practitioners can use the results of this study for designing jobs to attract and retain the best talents of the market. They can also consider new job attributes and conduct conjoint analysis to identify the most preferred job attributes. They can run simulation presented in this paper to design jobs with the highest possible utility for their prospective employees. Simulation exercises can also help practitioners get insights about the impacts of any changes in job attributes.

\section{References}

Andersen, L. B., Eriksson, T., Kristensen, N., \& Pedersen, L. H. (2012). Attracting public service motivated employees: how to design compensation packages. International Review of Administrative Sciences, 78(4), 615-641. http://dx.doi.org/10.1177/0020852312455298

Belt, J. A., \& Paolillo, J. G. (1982). The influence of corporate image and specificity of candidate qualifications on response to recruitment advertisement. Journal of Management, 8(1), 105-112. http://dx.doi.org/10.1177/ 014920638200800107

Browne, B. A. (1997). Gender and preferences for job attributes: A cross cultural comparison. Sex Roles, 37(1-2), 61-71. http://dx.doi.org/10.1023/A:1025688603525

Clark, A. E. (1998). What Makes a Good Job?: Evidence from OECD Countries. LEO-CRESEP.

Corrigall, E. A., \& Konrad, A. M. (2006). The relationship of job attribute preferences to employment, hours of paid work, and family responsibilities: An analysis comparing women and men. Sex Roles, 54(1-2), 95-111. http://dx.doi.org/10.1007/s11199-006-8872-y

Davis, J. A., \& Jowell, R. (1989). Measuring national differences: an introduction to the International Social Survey Programme (ISSP). British Social Attitudes: Special International Report, edited by Roger Jowell, Sharon Witherspoon, and Lindsay Brook. Aldershot: Gower, 1-13.

Fehr, E., Herz, H., \& Wilkening, T. (2013). The lure of authority: Motivation and incentive effects of power. American Economic Review, 103(4), 1325-1359. http://dx.doi.org/10.1257/aer.103.4.1325

Fombrun, C., \& Shanley, M. (1990). What's in a name? Reputation building and corporate strategy. Academy of management Journal, 33(2), 233-258. http://dx.doi.org/10.2307/256324

Gatewood, R. D., Gowan, M. A., \& Lautenschlager, G. J. (1993). Corporate image, recruitment image and initial job choice decisions. Academy of Management journal, 36(2), 414-427. http://dx.doi.org/10.2307/256530

Green, P. E., \& Srinivasan, V. (1978). Conjoint analysis in consumer research: issues and outlook. Journal of consumer research, 103-123. http://dx.doi.org/10.1086/208721

Green, P. E., Krieger, A. M., \& Wind, Y. (2001). Thirty years of conjoint analysis: Reflections and prospects. Interfaces, 31(3_supplement), S56-S73.

Herzberg, F. (1966). Motivate Employees? World, 88.

ILO. (1962). Reduction of Hours of Work Recommendation, 1962 (No. 116).

Islam, N., \& Saha, G. C. (2001). Job satisfaction of bank officers in Bangladesh. ABAC Journal, 21(3).

Jacobs, J. E., Finken, L. L., Griffin, N. L., \& Wright, J. D. (1998). The career plans of science-talented rural adolescent girls. American Educational Research Journal, 35(4), 681-704. http://dx.doi.org/10.3102/0002 8312035004681

Jurgensen, C. E. (1978). Job preferences (What makes a job good or bad?). Journal of Applied Psychology, 63(3), 267-276. http://dx.doi.org/10.1037/0021-9010.63.3.267

Kabir, M. N., \& Parvin, M. M. (2011). Factors affecting employee job satisfaction of pharmaceutical sector. Australian Journal of Business and Management Research, 1(9), 113-123.

Khaleque, A., \& Rahman, M. A. (1987). Perceived importance of job facets and overall job satisfaction of industrial workers. Human Relations, 40(7), 401-415. http://dx.doi.org/10.1177/001872678704000701 
Konrad, A. M. (2003). Family demands and job attribute preferences: A 4-year longitudinal study of women and men. Sex Roles, 49(1-2), 35-46. http://dx.doi.org/10.1023/A:1023957502570

Konrad, A. M., Corrigall, E., Lieb, P., \& Ritchie, J. E. (2000). Sex differences in job attribute preferences among managers and business students. Group \& Organization Management, 25(2), 108-131. http://dx.doi.org/10. $1177 / 1059601100252002$

Konrad, A. M., Ritchie Jr, J. E., Lieb, P., \& Corrigall, E. (2000). Sex differences and similarities in job attribute preferences: a meta-analysis. Psychological bulletin, 126(4), 593-641. http://dx.doi.org/10.1037/0033-2909. 126.4.593

Lauver, K. J., \& Kristof-Brown, A. (2001). Distinguishing between employees' perceptions of person-job and person-organization fit. Journal of Vocational Behavior, 59(3), 454-470. http://dx.doi.org/10.1006/jvbe.20 01.1807

Maslow, A. H. (1943). A theory of human motivation. Psychological review, 50(4), 370-396. http://dx.doi.org/10. 1037/h0054346

McCullough, D. (2002). A user's guide to conjoint analysis. Marketing Research, 14(2), 18-23.

Miller, R. A. (1984). Job matching and occupational choice. The Journal of Political Economy, 1086-1120. http://dx.doi.org/10.1086/261276

Morgan, C., Isaac, J. D., \& Sansone, C. (2001). The role of interest in understanding the career choices of female and male college students. Sex Roles, 44(5-6), 295-320. http://dx.doi.org/10.1023/A:1010929600004

Pinder, C. C. (1998). Motivation in work organizations. Upper Saddle River, NJ.

Rashid, A., \& Lodh, S. C. (2008). The influence of ownership structures and board practices on corporate social disclosures in Bangladesh. Research in Accounting in Emerging Economies, 8(1), 211-237. http://dx.doi.org/10.1016/S1479-3563(08)08008-0

Reynolds, J. (2005). In the face of conflict: Work - life conflict and desired work hour adjustments. Journal of Marriage and Family, 67(5), 1313-1331. http://dx.doi.org/10.1111/j.1741-3737.2005.00219.x

Rose-Ackerman, S. (1996). Altruism, nonprofits, and economic theory. Journal of economic literature, 701-728.

Rynes, S. L. (1989). Recruitment, job choice, and post-hire consequences: A call for new research directions. CAHRS Working Paper Series, 398-460.

Schwab, D. P., Rynes, S. L., \& Aldag, R. J. (1987). Theories and research on job search and choice. Research in Personnel and Human Resources Management, 5(1), 129-166.

Sutherland, J. (2011). Job attribute preferences: who prefers what? Employee Relations, 34(2), 193-221. http://dx.doi.org/10.1108/01425451211191896

Tolbert, P. S., \& Moen, P. (1998). Men's and Women's Definitions of “Good” Jobs Similarities and Differences by Age and Across Time. Work and Occupations, 25(2), 168-194. http://dx.doi.org/10.1177/073088849802 5002003

Turban, D. B., \& Campion, J. E. (1993). Job attributes: Preferences compared with reasons given for accepting and rejecting job offers. Journal of Occupational and Organizational Psychology, 66, 71-81. http://dx.doi.org/10.1111/j.2044-8325.1993.tb00517.x

Wilcox, R. T. (2008). A practical guide to conjoint analysis. Darden Case No.UVA-M-0675. Retrieved from http://ssrn.com/abstract $=1280602$

\section{Copyrights}

Copyright for this article is retained by the author(s), with first publication rights granted to the journal.

This is an open-access article distributed under the terms and conditions of the Creative Commons Attribution license (http://creativecommons.org/licenses/by/3.0/). 